\title{
DEVELOPING COMMUNICATIVE GRAMMAR MATERIALS FOR TEACHING SPEAKING IN THE ELEVENTH GRADE OF KALAM KUDUS SENIOR HIGH SCHOOL BALI.
}

\author{
J. Polin', L.P. Artini' ${ }^{2}$ I.G. Budasi ${ }^{3}$ \\ ${ }^{123}$ English Language Education, Post Graduate Program, Universitas Pendidikan Ganesha, Singaraja \\ e-mail: junias.polin@pasca.undiksha.ac.id, putu.artini@undiksha.ac.id, gede.budasi@pasca.undiksha.ac.id
}

\begin{abstract}
This study is aimed at: (I) finding out how need analysis is conducted for developing communicative grammar materials for teaching speaking in the eleventh grade of Kalam Kudus senior high school; (2) finding how Communicative Grammar Materials developed; (3) knowing the quality of the developed Communicative Grammar Materials for teaching speaking skill in the eleventh grade. This study applied Research and Development design proposed by Sugiyono (2010) which simplified into six steps, and Borg and Gall (1983) model was adapted to do need analysis. The study found that the obtained need analysis were conducted through observation, questionnaire, document analysis, and interview. The Communicative Grammar materials were developed using criteria proposed by Leech (2013) that is designed based on Hutchinson and Waters (1987) by considering the basic competency and indicators in the KTSP 2006 syllabus used at school and they topics developed; (1) giving and asking for opinion, (2), Expressing satisfaction and dissatisfaction, (3) Giving advice and responding to advice, (4) Expressing warning and responding to warning, (5) Accepting Invitation, (6) Expressing feeling of relief, pain, and pleasure, (7) Expressing love, (8) Expressing sadness, (9) Expressing Embarrassment, (10) Expressing anger and annoyance. The product of this study follows good criteria of teaching material which proposed by Leech (2013) and The quality of the product perceived by the expert judges was in a good category that is shown in the criteria and interval of $229(X=229)$ using Gregory (2010) formula.
\end{abstract}

\section{Key Words: Communicative grammar, teaching speaking skill}

\section{INTRODUCTION}

The grammar teaching has undergone through a lot of rethinking and number of discovery approach appears to be an alternative technique for teaching grammar. Communicative grammar for instance as a fresh departure in grammar teaching approach. It focuses on communicative grammar point rather than memorization. It enables students with sufficient information to illustrate particular grammatical features that give opportunity to explore the examples and draw conclusions on the particular grammatical structures. The shifts of grammar teaching philosophy from the old-fashion method to an up-to-date grammar teaching approach brings possible change in English learning and teaching process. Current grammar teaching trend has undergone great changes however, it is still considered standstill as there is no significant impact on students' progress.

This reality originates from the facts that most teachers still use old-fashion grammar teaching approach. Traditionally, grammar teaching is still dominated by conventional ways that emphasis is on English language rules memorization that still being applied for several decades and become the most effective choice used by many English teachers. Unfortunately this grammar teaching approach is only creating a traumatic learning experience for English as a foreign language(EFL) learners. According to Alwasilah (2001) and Mistar (2005), the grammar driven methodology is not adequate to enable students to communicate well and does not support the learners to think critically.

The problem is why so-called grammar teaching technique is still permitted for decades in Indonesian education system. It can be observed in all the teaching activities are always grounded on the grammar translation and memorization teaching and learning styles. Another problem that caused the grammar teaching never shifts from old fashion style to a 
communicative ways is the curriculum changed. Even though the amendment of curriculum 1984, 1994 and 2004 shifted to a more communicative oriented however, the teachers still cling on the grammar translation mindset.

In spite, the competency -based curriculum is implemented through KTSP (school based curriculum) which gives more space for schools and teachers to develop the teaching approach based on the teaching and learning needs, however, many teachers still unable to think outside the box, to implement the competency based learning purpose to a real result. KTSP curriculum implementation tends to put forward result orientation rather than the communicative process. Consequently, the learning result is not appropriately achieved as it requires high quality and professional creative teachers to implement it meanwhile most of the teachers as the front liners are not ready and are not well-prepared by the central government. Observing the grammar teaching approach use in eleventh grade of Kalam Kudus senior high school which still rely on grammar translation method, the researcher decided to develop and introduce communicative grammar materials as proposed by Leech (2013) with the four circles of communicative grammar teaching approach that is considered to be able to boost teacher's teaching creativity and students' curiosity to learn English effectively.

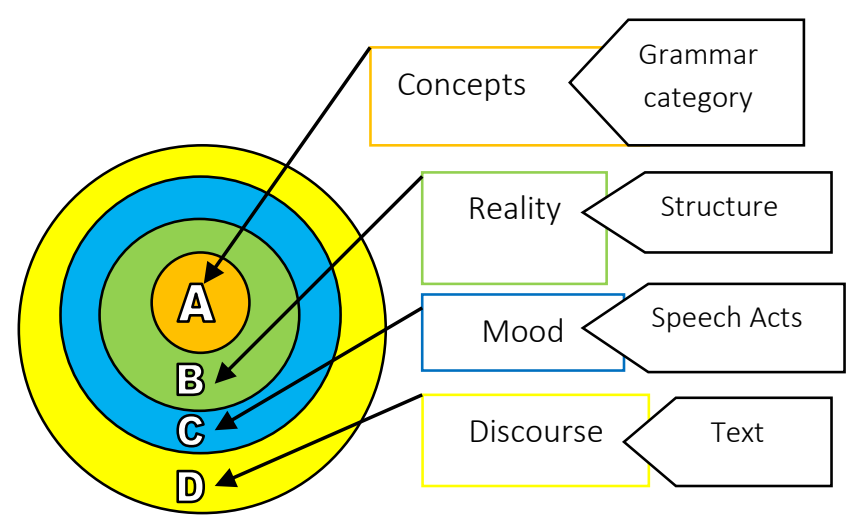

Figure 01: CG scheme by Leech (simplified)

\section{METHOD}

The study was design by using reserach and development proposed by Sugiyno. The consideration of choosing this The considerations of choosing this design were 1) it was relevant to the focus of the development of the product, 2) comparing with other models, and 3 it provided more flexible steps of design validation. The data was collected from classroom observation, questionaire, interview, analysing curriculum and teaching materials. The subject were the English teacher and students of the eleventh grade of Kalam Kudus Senior high school.

\section{FINDING DAN DISCUSSION}

To respond to the research question, "how is need analysis conducted to develop communicative grammar materials for teaching speaking?", a need analysis was carried out to collect necessary information. The data then stemmed from the observation, syllabus analysis, questionnaire, and interview results. The study was focused on four aspects of language teaching; speaking, grammar, vocabulary, and pronunciation. Data of the research drown from 28 students and one English teacher as respondents. The data shows that the students and teacher need well-developed communicative teaching materials for teaching and learning speaking. 
Table: 01 Need Analysis

\begin{tabular}{ccccc}
\hline Aspects & Items & Respondents & Agree & Disagree \\
\hline Speaking & 10 & 29 & $83 \%$ & $17 \%$ \\
Grammar & 10 & 29 & $93 \%$ & $7 \%$ \\
Vocabulary & 10 & 29 & $92 \%$ & $8 \%$ \\
Pronunciation & 5 & 29 & $100 \%$ & -
\end{tabular}

After collecting the data from the research conducted for two months, the researcher drew several significant points from the teaching and learning process involving four language aspects.

First, the result of observation of the four aspects; speaking, grammar, vocabulary and pronunciation. It was found that, the speaking aspect was taught through reading where students were asked to read text and fill in the gaps. This approach really limits the students to express their ideas in oral form. It really contrasts to Savignon (2007), "the essence of language teaching is to engage learners in communication to allow them to develop their communicative competence". Still in line with the interview result, most $f$ the students wished they could be given more chance to practice speaking. The grammar part teaching was carried out by driving the students to remember the language formulas. Many students said, memorizing language formulas really difficult. They prefer learning those language rules through a communicative model. Meanwhile vocabulary teaching was carried out through antonym and synonym word matching that made students became passive in the speaking classroom.

Second, the result of questionnaire of the 28 respondents shows that the students need a communicative student-centered approach where the language teaching is carried out communicatively and they are given more chance to practice. The data still in line with the facts found during the observation period where the materials were not communicatively taught. Based on the result the questionnaire, all the students wanted more communicative grammar materials to improve their speaking competency.

The results show that both English teacher and students agreed to that communicative grammar materials needed to be developed to support students' speaking ability. Communicative grammar materials give opportunity for teacher to teach effectively and opportunity for students to practice, practice, and practice more.

Third, the interview was conducted to all the students, and the result was still relevant to the information obtained during the observation and the questionnaire result. All the students and teacher agreed to have a more communicative grammar teaching materials to support their speaking competency. The interview result of the 28 students, shows that they speaking is taught in communicative manner where they are given more chance to express their ideas. The also prefer to learn vocabulary through content and context approach where have unlimited access to English texts as well as functional and narrative text explore, develop and enrich their vocabulary without memorizing one by one word.

Fourth, another difficult part for students in learning speaking skill was utterance or pronunciation. The students found difficulties in dealing with phonological symbols and they wanted to have a simple pronunciation approach. Generally, the results of both teacher and students show that they really expect for a more communicative grammar materials for teaching speaking to improve the students' speaking competency.

Based on the results of the need analysis, the materials design grid was sketched based on the students' need analysis. The Communicative Grammar materials were developed to cover speaking, grammar, vocabulary, and pronunciation and the simulation process is carried out as well as individually and in group. 


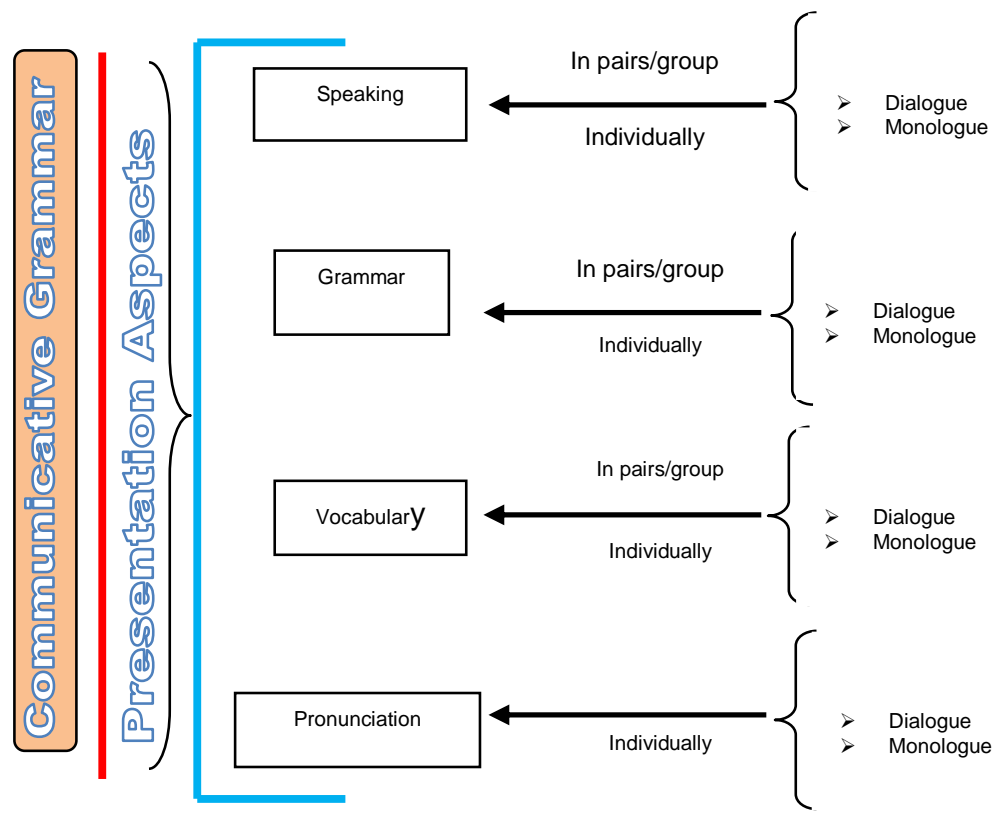

Figure 02: Communicative grammar

To answer the research question, "How are the communicative grammar materials for teaching speaking developed?. Based on the KTSP syllabus and the Basic Competency and indicators, the communicative grammar materials were developed into ten topics, namely; (1) Giving and asking for opinion, (2) expressing satisfaction and dissatisfaction, (3)giving advice, (4) expressing warning (5) accepting invitation (6) expressing relief, pain, pleasure, (7) expressing love, (8) expressing sadness, (9) Expressing embarrassment, and (10) expressing anger and annoyance.

The content of materials is designed for speaking purpose therefore, all the activities are supposed to be carried out in oral presentation forms.

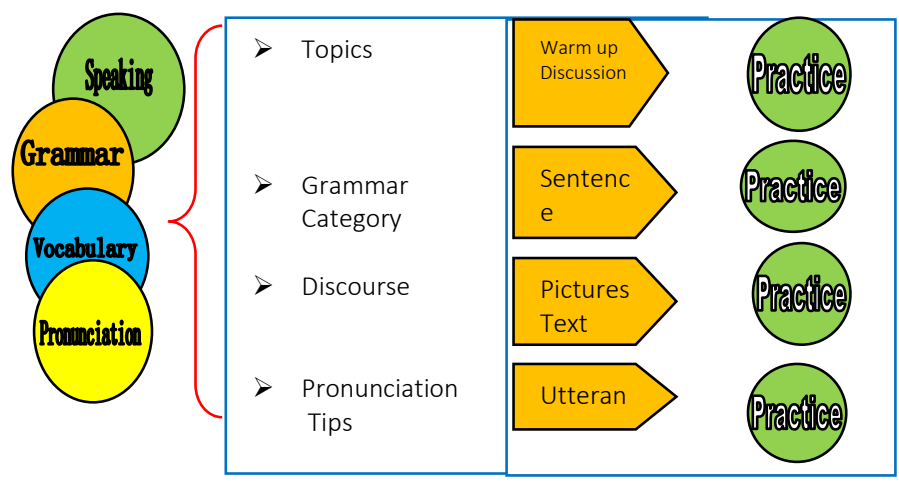

Figure 03: Communicative grammar materials design

Each aspect gives opportunity for students to practice and express their ideas orally, Speaking topic provides warm-up section where students are expected to talk about hot issue within the society. Presenting everyday phenomenal issue may trigger the students to express their point of view freely. The dialogues are transactional to get something done. The grammar part covers English parts of speech; meaning, examples and oral exercises. Meanwhile, for vocabulary enrichment, it is provided with text and pictures that enable students to speak up using the visual aids and instructions. These communicative grammar materials are supplied with pronunciation tips, general knowledge and proverbs that make the learning interesting and meaningful. To complete research question \#3 what is the quality 
of the developed communicative materials, the two judges gave their evaluation. The score of the experts shows in the internal consistency (reliability test) performed to calculating the coefficient (Cronbach) alpha of each instrument in one variable. The instruments used in the variable is said to be reliable (reliability) hence the Reliability statistics score more than 0.60 Alpha Cronbach's (Nunnaly in Imam Ghozali, 2001) and the product is considered to be excellent.

\section{Conclusion}

The main goal of developing this communicative grammar material is for teaching speaking skill in the eleventh grade of Kalam Kudus Senior High School. This study used research and development design suggested by Sugiyono(2010) and for the purpose of analysis the study adapted Borg Gall(1987) design model to conduct need analysis. The need analysis was conducted through questionnaire, document analysis and interview. Based on the need analysis, there were ten topics developed based on the basic competency and indicators in KTSP 2006 syllabus used at school, they are; developed topics are: (1) Giving and asking for opinion, (2) expressing satisfaction and dissatisfaction, (3)giving advice, (4) expressing warning (5) accepting invitation (6) expressing relief, pain, pleasure, (7) expressing love, (8) expressing sadness, (9) Expressing embarrassment, and (10) expressing anger and annoyance. The communicative grammar materials were developed in reference to Leech(2013) and the design based on Hutchinson and Waters (1987). The productr was then evaluated by the expert judges and the quality of the product is considered to be in good category that is shown in the criteria and interval of 229 (X-229) using Gregory (2010) formula.

\section{REFERRENCES}

Alwasilah, C. A. (2001). Language, culture and education . Bandung: Andira.

Education Ministerial Regulation (2006). Standard of Content. Jakarta Department of National Education of Republic of Indonesia.

Leech, G \& Svartvik J, (2013), Communicative Grammar, Routledge; 3 edition (2013)

Mistar, J. (2005). Teaching English as a foreign language (TEFL) in Indonesia. In B. George (Ed.), Teaching English to the world: History, curriculum, and practice, Mahwah, NJ: Lawrence Erlbaum Associates, pp. 71-80.

Savignon, S. J. (2007). Beyond communicative language teaching: What's ahead? Journal of Pragmatics, 39(1), 207-220. doi:10.1016/j.pragma.2006.09.00

Sugiyono, Dr. 2010. Metode penelitian Kuantitatif Kualitatif dan R\&D, Penerbit ALFABETA

Ur, P. (1999). Grammar practice activities: A practical guide for teachers (12 ed.). Cambridge: Cambridge University Press. 